\title{
Colorimetric Chemosensor Array for Determination of Halides
}

\author{
Michal Šídlo ${ }^{1}$, Přemysl Lubal ${ }^{1, *}$ and Pavel Anzenbacher Jr. ${ }^{2}$ \\ 1 Department of Chemistry, Faculty of Science, Masaryk University, Kamenice 5, 62500 Brno, Czech Republic; \\ michal.s119@volny.cz \\ 2 Center for Photochemical Sciences and Department of Chemistry, Bowling Green State University, \\ Bowling Green, OH 43403, USA; pavel@bgsu.edu \\ * Correspondence: lubal@chemi.muni.cz; Tel.: +420-54949-5637
}

Citation: Šídlo, M.; Lubal, P.;

Anzenbacher, P., Jr. Colorimetric

Chemosensor Array for

Determination of Halides.

Chemosensors 2021, 9, 39.

https://doi.org/10.3390/

chemosensors 9020039

Academic Editor: Jose Vicente Ros Lis

Received: 31 December 2020

Accepted: 12 February 2021

Published: 18 February 2021

Publisher's Note: MDPI stays neutral with regard to jurisdictional claims in published maps and institutional affiliations.

Copyright: (C) 2021 by the authors. Licensee MDPI, Basel, Switzerland. This article is an open access article distributed under the terms and conditions of the Creative Commons Attribution (CC BY) license (https:/ / creativecommons.org/licenses/by/ $4.0 /)$.

\begin{abstract}
The halide anions are essential for supporting life. Therefore, halide anion analyses are of paramount importance. For this reason, we have performed both qualitative and quantitative analyses of halides (chloride, bromide, iodide) using the Tl(III) complex of azodye, 4-(2-pyridylazo)resorcinol (PAR), a potential new chemical reagent/sensor that utilizes the substitution reaction whereas the Tl(III)PAR complex reacts with a halide to yield a more stable thallium(III)-halide while releasing the PAR ligand in a process accompanied by color change of the solution. The experimental conditions (e.g., $\mathrm{pH}$, ratio metal ion-to-ligand ratio, etc.) for the substitution reaction between the metal complex and a halide were optimized to achieve increased sensitivity and a lower limit of detection (chloride $7 \mathrm{mM}$, bromide $0.15 \mathrm{mM}$, iodide $0.05 \mathrm{mM}$ ). It is demonstrated that this single chemosensor can, due to release of colored PAR ligand and the associated analyte-specific changes in the UV/VIS spectra, be employed for a multicomponent analysis of mixtures of anions (chloride + bromide, chloride + iodide, bromide + iodide). The spectrophotometric data evaluated by artificial neural networks (ANNs) enable distinguishing among the halides and to determine halide species concentrations in a mixture. The Tl(III)-PAR complex was also used to construct sensor arrays utilizing a standard 96-well plate format where the output was recorded at several wavelengths (up to 7) using a conventional plate reader. It is shown that the data obtained using a digital scanner employing only three different input channels may also be successfully used for a subsequent ANN analysis. The results of all approaches utilized for data evaluation were similar. To increase the practical utility of the chemosensor, we have developed a test paper strip indicator useful for routine naked-eye visual determination of halides. This test can also be used for halide anion determination in solutions using densitometer. The methodology described in this paper can be used for a simple, inexpensive, and fast routine analysis both in a laboratory as well as in a field setting.
\end{abstract}

Keywords: metal complex; halide analysis; anion chemosensor; artificial neural network (ANN); multicomponent analysis; microplate reader/digital scanner; test strip paper(s)

\section{Introduction}

Halide $\left(\mathrm{Cl}^{-}, \mathrm{Br}^{-}, \mathrm{I}^{-}\right)$salts are widely present in nature and play important roles in biological and environmental processes where their presence and concentration determine the state of homeostasis and, for example, quality of natural mineral and/or drinking waters [1]. From the physiological point of view, the halide anions are essential for life, but in extensive amounts they may also be toxic [2,3]. In addition, they are also used as raw materials in numerous industrial processes. Due to the wide impact of $\mathrm{Cl}^{-}, \mathrm{Br}^{-}$, and $\mathrm{I}^{-}$anions there is a need for fast, inexpensive, and practical methods for halide anion determination. Currently, a variety of analytical techniques for halide determination is available. Classical methods such as titrimetry (argentometry) and gravimetry using precipitation reactions between silver and halide ions gave way to electroanalytical methods using halide ion-selective electrodes (ISE's) and/or coulometric titrations, which are now preferred [4-6]. Modern separation techniques, e.g., ion-exchange chromatography [1], 
electromigration techniques, capillary electrophoresis/isotachophoresis [7-9], are mostly employed for the analysis of halides in mixtures and complex matrixes. In addition, some optical chemosensors based on interaction of supramolecular receptors with halides with simultaneous change of absorbance/fluorescence were also described [2,3,10-35]. While the above methods are generally reliable and deliver good results, they tend to be expensive and not always useful for field analyses. Aiming at addressing these potential hurdles, we have investigated simple and inexpensive materials and techniques that would allow for reliable analyses using simple and disposable halide sensors.

The azodyes (e.g., PAR, PAN/PANS, TAR, 3,5- $\mathrm{diBr}_{2} \mathrm{PADAP}$ ) are well known as widely used chromogenic reagents for determination of several metal ions [36-39].

Unfortunately, in some cases, the metal ion determination is hampered by the presence of interfering anions, e.g., halides, which can form more stable less colored or colorless complexes and therefore act as masking agents. On the other hand, this phenomenon can also be employed for indirect determination of such anionic species [3,12,15,22]. The substitution reaction of analytes, e.g., anions, oligopeptides, oligonucleotides, etc., with metal complexes:

$$
\mathrm{MR}+\text { Analyte } \Leftrightarrow \mathrm{M} \text { (Analyte) }+\mathrm{R}
$$

can be utilized for sensing using arrays which enable carrying out the qualitative and quantitative analysis aided by chemometric techniques [10-12,15,40].

In this paper, the interaction of Tl(III)-PAR complex with halides was investigated by molecular absorption spectrometry, and the application of this complex in the form of single chemosensor arrays for qualitative as well as quantitative analyses of halides in mixture is demonstrated. The application of silver(I) and mercury(II) complexes of 3,5- $\mathrm{diBr}_{2} \mathrm{PADAP}$ (Figure 1) which is similar by chemical structure to PAR for qualitative determination of halides [3] was used for their identification in the presence of other anions including fluoride, sulphate, phosphate and nitrite in water samples [19]. To overcome problems related to the formation of possible precipitates of electroneutral salts such as $\mathrm{AgX}$ and $\mathrm{HgX}_{2}[3,19]$, the use of the new Tl(III)-PAR system and the corresponding multicomponent halide analysis was investigated, and the results are described in this paper.
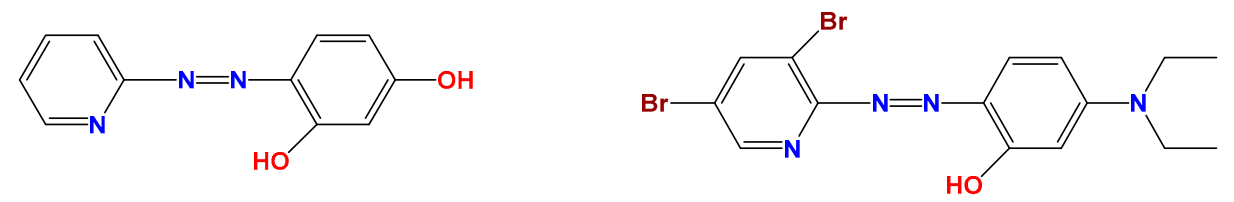

Figure 1. The structure of 4-(2-pyridylazo) resorcinol (PAR, left) and 2-(3,5-dibromo-2-pyridylazo)-5(diethylamino)-phenol (3,5-diBr 2 PADAP, right).

\section{Materials and Methods}

Doubly distilled water was used for preparation of all solutions. Chemicals, 4-(2pyridylazo)resorcinol) (PAR), potassium bromide, potassium iodide, acetic acid (all analytical grade purity) were obtained from the Lachema company (Brno, Czech Republic) while potassium chloride and thallium(III) oxide were purchased from Fluka (Buchs, Switzerland), and sodium hydroxide from Merck (Darmstadt, Germany). Thallium(III) perchlorate was prepared dissolving thallium(III) oxide in excess of perchloric acid, and the metal ion content was determined chelatometrically $[36,41,42]$ while the acid content was estimated from Gran transformation of thallium(III) standard solution [41-44].

The solution of $\mathrm{Tl}(\mathrm{III})$ complex was prepared from thallium(III) perchlorate and PARazodye solutions in the metal:ligand ratio of $1: 1 / 1: 2$ in an acetate buffer $(c=0.01 \mathrm{M}$, $\mathrm{pH}=4.0)$, the paper sensor was prepared by using the solution in the ratio $1: 1$ in acetate buffer $(c=0.05 \mathrm{M}, \mathrm{pH}=4.0)$. The solution of the metal complex was always prepared fresh in order to ensure the reproducibility of halide analysis. The halide analysis was carried out for concentration region: chloride $10-50 \mathrm{mM}$, bromide $0.4-1.9 \mathrm{mM}$, iodide $0.038-0.107 \mathrm{mM}$. 
Test strip preparation was carried out very fast by soaking the common filtration paper in the 1:1 ratio of thallium (III) perchlorate and PAR, followed by drying in the desiccator to eliminate carbon dioxide from the air. The thallium salts are known to be toxic $[42,45,46]$. Due to the higher mobility and similarity to potassium ion $\mathrm{Tl}(\mathrm{I})$ is more toxic than $\mathrm{Tl}(\mathrm{III})$, which is used, for example, in medicine $\left({ }^{201} \mathrm{Tl}\right.$ in nuclear cardiography for thallium stress test $[42,45,46])$.

All absorbance or reflection measurements were carried out at laboratory temperature using spectrophotometer Cary $50 \mathrm{UV}$-Vis (Varian, Australia). The analysis by means of sensor arrays was realized using a microplate reader SUNRISE (Tecan, Austria) or a digital scanner EPSON V750 (EPSON, Indonesia). The strip evaluation was performed by using the densitometer X-Rite model 810 (X-Rite, Grand Rapids, MI, USA). The pH of solutions was determined using ORION 2-STAR pH meter (ThermoScientific, Waltham, MA, USA).

The original experimental data were exported into the program Excel and treated by Principal Component Analysis (PCA) of STATISTICA software (StatSoft, Bedford, UK) or by artificial neural network (ANN) and PCA by QC-Expert company (Trilobyte, Pardubice, The Czech Republic). The experimental data from a digital scanner were obtained using the software supplied with the scanner.

The spectral data used for the analysis were obtained as follows: Absorption spectra at the range of wavelengths of 350-600 $\mathrm{nm}$ in $5 \mathrm{~nm}$ intervals were used as the inputs in ANN (51 input neurons in total) while the concentrations of one-component (1 neuron) or two-components (2 neurons) for the mixtures of halides were used as the output values. The ANN of architecture 7: X: 2 was used for the experimental data obtained from the plate reader where 7 input neurons correspond to absorbances at 400, 450, 500, 520, 550, 600, $650 \mathrm{~nm}, 2$ output neurons were used for concentration of halides in model mixtures, and $X$ was the optimized number of neurons in one and/or two hidden layers. Similarly, ANN of architecture 3: X: 2 was employed for experimental data obtained from digital scanner. In the case of the scanner, the so-called effective absorbance for red, green, and blue (RGB) channel was used. The effective absorbance is defined as follows:

$$
A=-\log \left(I / I_{\mathrm{B}}\right)
$$

where $I$ and $I_{\mathrm{B}}$ are intensities of sample and blank at a selected channel. The ANN architecture, i.e., determination of the number of hidden layers and neurons in those layers was optimized and trained for given experimental data. The network with the smallest (minimal) training and testing error was selected for prediction of concentration of halides.

\section{Results and Discussion}

\subsection{Development of Halide Sensor}

Thallium(III) ion and PAR azodye ligand forms complexes of 1:1 and 1:2 stoichiometry [43,47-49] and their concentrations in solution depend on experimental conditions (e.g., $\mathrm{pH}$, ligand-metal ion ratio-see Appendix A for more details). At $\mathrm{pH}>3$, the formation of 1:2 complex is formed quantitatively while the abundance of 1:1 complex is observed at $\mathrm{pH} \sim 1$ (see Figure A2). Since some common buffers of higher concentration $(>0.05 \mathrm{M})$ are interfering with the Tl(III) complex formation [47], the acetate buffer $(c=0.01$ $\mathrm{M}$ ) was used to adjust the $\mathrm{pH}$ to $\mathrm{pH} \sim 4.0$ to prevent the possible reduction of $\mathrm{Tl}^{3+}$ to $\mathrm{Tl}^{+}$, which could take place at $\mathrm{pH}<1$ in the presence of halide $\mathrm{X}^{-}[41,42,44]$ :

$$
\mathrm{Tl}^{3+}+2 \mathrm{X}^{-} \rightarrow \mathrm{Tl}^{+}+\mathrm{X}_{2}
$$

The UV-vis spectrum of Tl(III)PAR complex (Figure 2) is dominated by two maxima of absorption bands at $520 \mathrm{~nm}$ and $400 \mathrm{~nm}$. Addition of a halide anion to the solution of the Tl(III) complex leads to a decrease of the absorption band of the metal complex at $520 \mathrm{~nm}$ while a new absorption band corresponding to the free PAR ligand appears at $400 \mathrm{~nm}$ (see Figure 2). Additionally, in the case of chloride and bromide anions, the diffuse isosbestic points are observed. In contradistinction, in the case of iodide the evolution of 
new absorption bands is observed. The PCA of spectral data presented in Figure 2 shows that the number of light-absorbing species in solution is 2 for chloride (TlL $+\mathrm{L}$ ), 3 for bromide (TlL $+\mathrm{L}+\mathrm{TlBr}_{4}{ }^{-}$), and 5 for iodide (see Table 1), respectively.
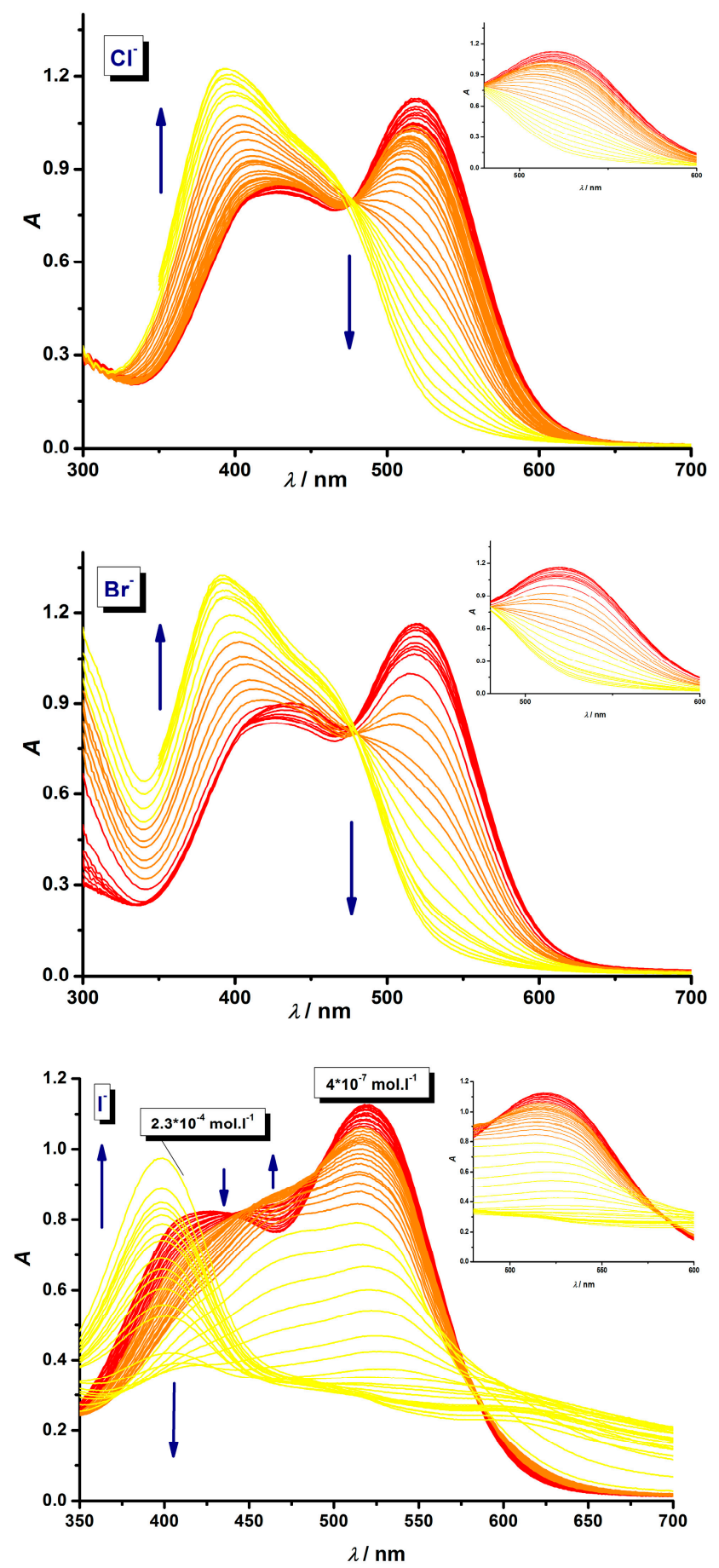

Figure 2. The examples of change in absorption spectra of Tl-PAR complex $\left(c_{\mathrm{Tl}} \sim 0.1 \mathrm{mM}\right.$, ratio 1:1) after addition of halides in the concentration region of $10^{-5}-10^{-1} \mathrm{M}$ (for more experimental details see Figure 3). 


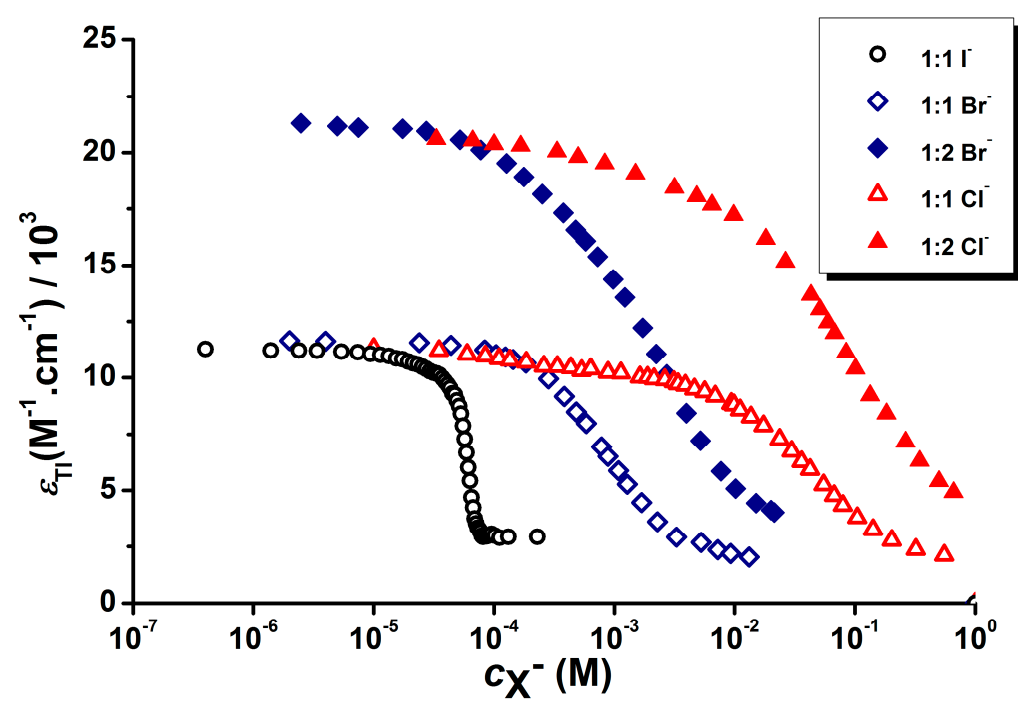

Figure 3. The dependence of molar absorption coefficient of Tl(III)-PAR complex on halide concentration measured at $520 \mathrm{~nm}$ (see examples in Figure 2). The open symbols are for Tl(III)-PAR complex in 1:1 ratio, the full symbols for Tl(III)-PAR complex in 1:2 ratio, the circle symbols are for iodide, the rectangle symbols are for bromide and the triangle symbols are for chloride.

Table 1. The results of PCA analysis of absorption spectra for selected wavelengths. (400, 450, 500, $520,550,600,650 \mathrm{~nm}$ ) (see Figure 2). The bold numbers mean the number of light-absorbing species in solution estimated according to CTV.

\begin{tabular}{ccccccc}
\hline & $\begin{array}{c}\text { Eigenvalue } \\
\mathrm{Cl}^{-}\end{array}$ & CTV \% & $\begin{array}{c}\text { Eigenvalue } \\
\mathbf{B r}^{-}\end{array}$ & CTV \% & $\begin{array}{c}\text { Eigenvalue } \\
\mathbf{I}^{-}\end{array}$ & CTV \% \\
\hline $\mathbf{1}$ & $\mathbf{4 . 8 3 8 7}$ & $\mathbf{9 6 . 7 7 3 4}$ & $\mathbf{4 . 7 2 8 7}$ & $\mathbf{9 4 . 5 7 4 2}$ & $\mathbf{2 . 6 5 9 1}$ & $\mathbf{5 3 . 1 8 1 1}$ \\
$\mathbf{2}$ & $\mathbf{0 . 1 6 0 5}$ & $\mathbf{9 9 . 9 8 4 3}$ & $\mathbf{0 . 2 6 8 9}$ & $\mathbf{9 9 . 9 5 1 3}$ & $\mathbf{1 . 7 8 1 2}$ & $\mathbf{8 8 . 8 0 5 6}$ \\
$\mathbf{3}$ & 0.0005 & 99.9936 & $\mathbf{0 . 0 0 2 1}$ & $\mathbf{9 9 . 9 9 2 6}$ & $\mathbf{0 . 3 4 2 4}$ & $\mathbf{9 5 . 6 5 4 4}$ \\
$\mathbf{4}$ & 0.0003 & 99.9994 & 0.0002 & 99.9972 & $\mathbf{0 . 1 9 3 4}$ & $\mathbf{9 9 . 5 2 3 4}$ \\
$\mathbf{5}$ & 0.0000 & 100.0000 & 0.0001 & 100.000 & $\mathbf{0 . 0 2 3 8}$ & $\mathbf{1 0 0 . 0 0 0}$ \\
\hline
\end{tabular}

$\overline{\mathrm{CTV}}=$ Cumulative Total Variance.

In case of iodide, some ternary-colored species may be formed (except other colored species TlL, $\mathrm{L}, \mathrm{TlI}_{4}{ }^{-}$) and this can be explained by the fact that the formation of ternary complexes is probably followed by substitution reaction (the charges of species are omitted for the sake of clarity):

$$
\begin{gathered}
\mathrm{TlL}+m \mathrm{X}^{-} \leftrightarrow \mathrm{TlLX}_{m} \\
\mathrm{TlLX}_{m}+n \mathrm{X}^{-} \leftrightarrow \mathrm{TlX}_{m+n}+\mathrm{L}
\end{gathered}
$$

The colored TlLX $m$ species are only formed in case of iodide. Due to the higher stability constant of $\left[\mathrm{TlX}_{4}\right]^{-}$complex species $\left(\log \beta_{4}=19.2-19.7\right.$ for $\mathrm{Cl}^{-}, 26.3-26.5$ for $\mathrm{Br}^{-}, 35.7$ for $\mathrm{I}^{-}(I=4 \mathrm{M},[44,50-52])$, the equilibrium constant of substitution reaction (D) is higher for iodide than for other halides, i.e., bromide and chloride (Tables A1 and A2). Consequently, this reaction is taking place at lower concentration of iodide (see Figure 3). The slightly acidic $\mathrm{pH}$ employed in analysis eliminates interference of cyanide $\left(\log \beta_{4}=42.6\right.$ [52]) which forms with Tl(III) ion more stable complexes than Tl(III) with halides.

The 1:2 ratio of metal ion to azodye was also studied in order to increase the sensitivity of the substitution reaction (Figure 3) but no dramatic improvement was observed. The basic analytical parameters (i.e., sensitivity, limit of detection-see Table 2) were obtained by using calibration titration dependence in Figure 3. In addition, these experimental data can be used for estimation of stability constant of 1:2 complex (see Table A2 for Tl(III)-PAR) which are not found in the literature (see Appendix A). This estimated value agrees with the stability constant calculated for $\mathrm{Tl}(\mathrm{III})$ complex of PANS ligand. Therefore, this system 
can be also used for modelling of distribution diagrams of Tl(III) complexes in the presence of halides (Figure A2).

Table 2. The statistical parameters for the halide sensor based on the Tl(III)-PAR system. For the sake of clarity, the standard deviations of parameters are given in parentheses.

\begin{tabular}{cccc}
\hline $\mathbf{X}^{-}$ & $\begin{array}{c}\text { Detection Limit } \\
(\mathbf{m M})\end{array}$ & Dynamic Range (mM) & Sensitivity $\pm \mathbf{s}\left(\mathbf{M}^{-\mathbf{1}}\right)$ \\
\hline $\mathrm{Cl}^{-}$ & $6.7^{\mathrm{b}} ; 8.7^{\mathrm{c}}$ & $7-200^{\mathrm{b}}, 9-370^{\mathrm{c}}$ & $6.5(4)^{\mathrm{b}} ; 3.2(3)^{\mathrm{c}}$ \\
$\mathbf{B r}^{-}$ & $0.2^{\mathrm{bc}}$ & $0.2-3.0^{\mathrm{b}}, 0.2-12.4^{\mathrm{c}}$ & $518(20)^{\mathrm{b}} ; 230(16)^{\mathrm{c}}$ \\
$\mathbf{I}^{-}$ & $0.04^{\mathrm{b}}$ & $0.047-0.073^{\mathrm{b}}, 0.02-0.04^{\mathrm{c}}$ & $2.92(6) \times 10^{4} \mathrm{~b}^{\mathrm{b}} ; 1.34(2) \times 10^{3 \mathrm{ac}}$ \\
\hline
\end{tabular}

a_Sensitivity determined from kinetic determination (standard deviation in M.s) ${ }^{-1}{ }^{b}{ }^{\mathrm{b}}$ - Tl(III):PAR $=1: 1$, c_Tl(III):PAR = 1:2

As can be seen in Table 2, the sensor shows the best parameters for iodide. The substitution reaction between the iodide and the $\mathrm{ML}_{2}$ complex is slow because it consists of several steps including the formation of ternary complexes. The iodide can be determined by measurement of the initial reaction rate of the first step of the substitution reaction as a function of the iodide concentration (see Figure 4). To overcome the kinetic problems for the iodide determination we decided to use the ML complex only.

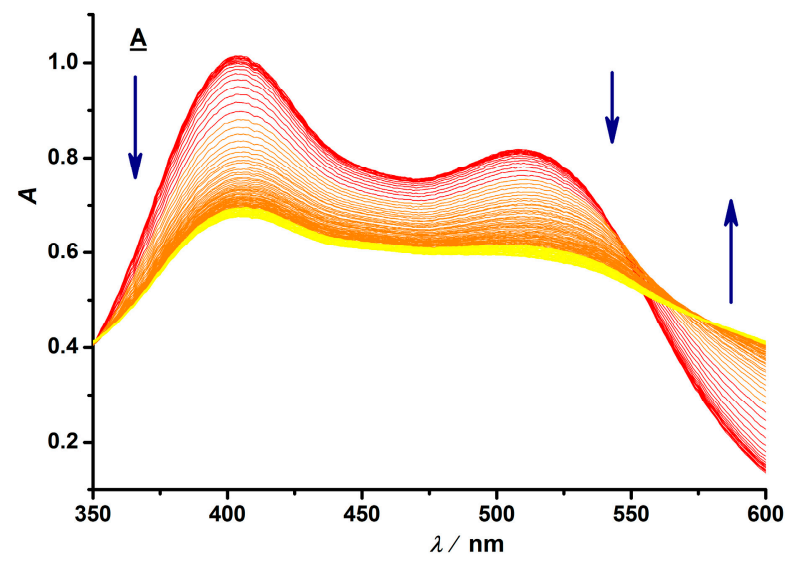

(a)

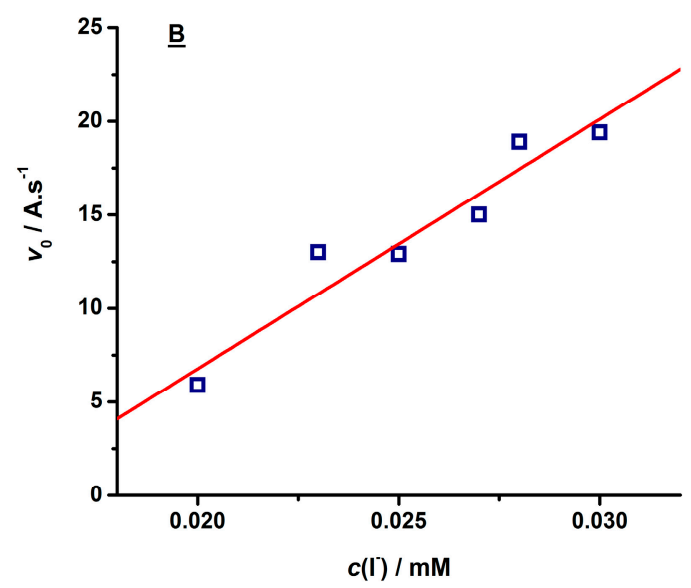

(b)

Figure 4. Time dependence of change of absorption spectra for the system Tl(III) $-\mathrm{PAR}_{-} \mathrm{I}^{-}$(Tl(III):PAR $=1: 2, c_{\mathrm{Tl}}=5.10^{-5} \mathrm{M}$, $\left.c_{\mathrm{I}}=3.10^{-5} \mathrm{M}, \Delta t=6 \mathrm{~s}\right)($ a) recorded at wavelength $520 \mathrm{~nm}$, which was used for the construction of a calibration plot initial rate $=\mathrm{f}\left(c_{\mathrm{I}}\right)(\mathbf{b})$.

The selectivity of the studied chemosensor for other anions was also tested (see Table 3). The tolerance for all anions is very high (up to $1000 \times$ related to halide concentrations). Exception is a nitrite, presumably because of the redox reaction between the metal ion and this anion. In addition, some metal ions (e.g., $\mathrm{Mg}$ (II), $\mathrm{Ca}$ (II) and about 100-times excess over $\mathrm{Tl}(\mathrm{III})$ - $\mathrm{Cd}(\mathrm{II}), \mathrm{Zn}(\mathrm{II}), \mathrm{Al}(\mathrm{III})$, and $\mathrm{Mn}(\mathrm{II})$ ) do not interfere the existence of $\mathrm{Tl}(\mathrm{III})$ complexes in solution $[47,48,53,54]$ making this sensors suitable for applications for multicomponent halide determination in natural and spring waters. In the presence of other metal ions, for example $\mathrm{Cu}$ or $\mathrm{Fe}$, the halide analysis is still possible, however it may require their masking by complexing agents $[47,53,54]$. 
Table 3. The experimentally determined tolerance of $\mathrm{Tl}(\mathrm{III})$ sensor to other anions $\left(c_{\text {sensor }}=0.1 \mathrm{mM}\right)$.

\begin{tabular}{ccc}
\hline Anion & Concentration $(\mathbf{m M})$ & Tolerance Ratio \\
\hline $\mathrm{SO}_{4}{ }^{2-}$ & 120 & 1200 \\
$\mathrm{NO}_{2}{ }^{-}$ & 1.9 & 19 \\
$\mathrm{NO}_{3}{ }^{-}$ & 240 & 2400 \\
$\mathrm{CO}_{3}{ }^{-}$ & 24 & 240 \\
$\mathrm{HPO}_{4}{ }^{-}$ & 61 & 610 \\
Acetate $^{-}$ & 240 & 2400 \\
Oxalate $^{2-}$ & 30 & 300 \\
$\mathrm{~F}^{-}$ & 120 & 1200 \\
\hline
\end{tabular}

\subsection{Indirect Multicomponent Analysis of Halides}

As it was discussed in previous section, the substitution reaction between the $\mathrm{Tl}(\mathrm{III})$ PAR complex and halides can be used for the halide determination utilizing the ANN analysis. This advanced chemometrics procedure became a powerful tool for qualitative and quantitative analysis because brings the reliable results without any effect of noise on experimental data [55].

Firstly, the determination of a single halide was verified using a ML complex as a sensor. Spectral data in the range of wavelengths from $350 \mathrm{~nm}$ to $600 \mathrm{~nm}(5 \mathrm{~nm}$ intervals) were used as inputs into ANN while one output (halide concentration) was varied: For chloride in the range of concentration of $9.9 \times 10^{-3}-0.2 \mathrm{M}$, for bromide in the range $(0.28-3.3) \times 10^{-3} \mathrm{M}$, and for iodide in the range of concentration of $(4.1-7.3) \times 10^{-5} \mathrm{M}$ (see analogous Figure 5).

\section{INPUT: $\quad \underline{\text { HIDDEN }}$ OUTPUT: \\ LAYER:}

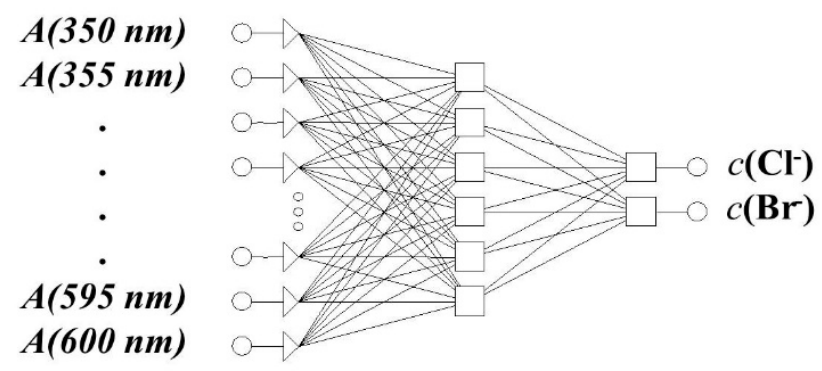

Figure 5. Example of optimal architecture (51:6:2) of artificial neural network (ANN) employed for $\mathrm{Cl}^{-}$and $\mathrm{Br}^{-}$analysis in mixture.

Secondly, the halide concentrations in binary mixtures were also determined. Here, the same halide concentrations as in case of single ion analysis were used for two outputs (Figure 5). The ANN architecture was optimized for the number of hidden layers and the number of neurons in layers, and the results for one or two hidden layers are comparable (see Figure 6). In addition, there is no systematic drift in prediction by one-layer or twolayer ANNs, which enables using the ANN with a simpler one-layer architecture.

Since the single chemosensor based on the Tl(III)-PAR complex was successful at predicting the halide concentrations in mixtures, the calibration matrix may be reduced by decreasing the number of wavelengths as well as the number of solutions $[15,17]$ without the loss of information. Thus, the spectral data for halide anions solutions as well as their mixtures (see Figure 7 as example) were recorded using seven selected wavelengths (400, $450,500,520,550,600,650 \mathrm{~nm}$ ) using the microplate reader. 

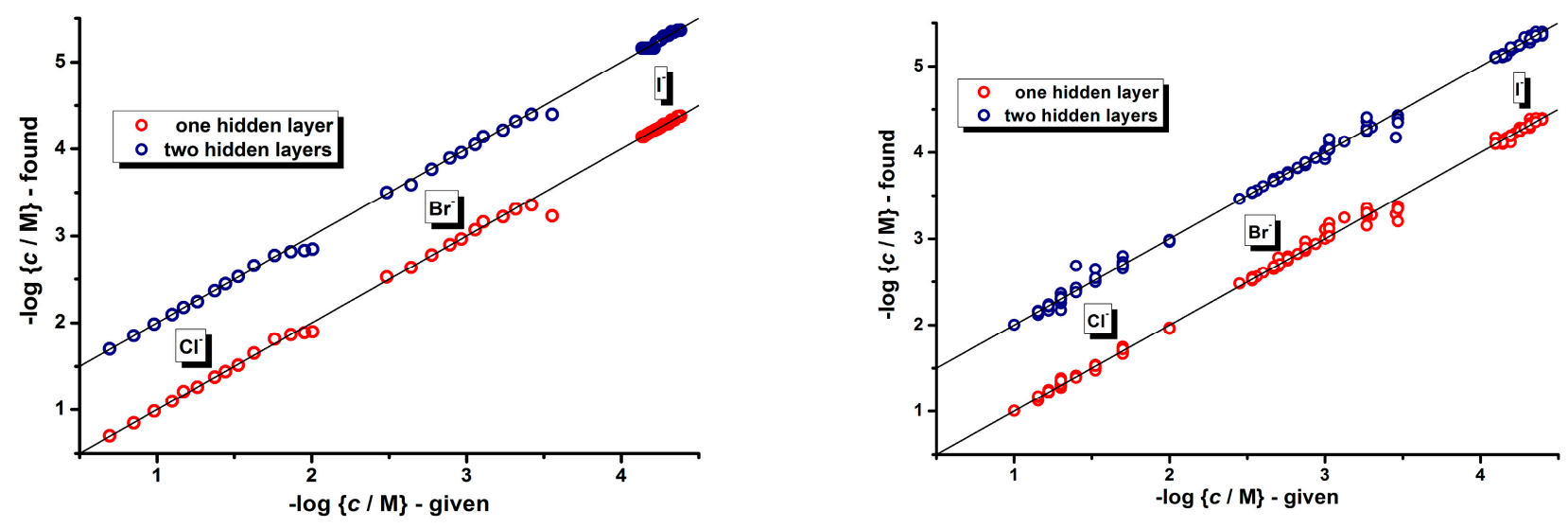

Figure 6. The results of analysis of single halides (left panel) or mixture of halides (right panel) by ANN analysis. The blue points were shifted by value +1 for the sake of clarity. The ANN architecture for single analysis with one hidden layer: 51:5:1 (chloride, bromide), 51:7:1 (iodide), two hidden layers: 51:4,5:1 (chloride), 51:5,6:1 (bromide), 51:6,7:1 (iodide). The ANN architecture for ana-lysis of mixture with one hidden layer: 51:7:2 (chloride-iodide), 51:6:2 (bromide-iodide, bromide-chloride), two hidden layers: 51:6,7:2 (chloride-iodide), 51:5,6:2 (bromide-iodide, bromide-chloride).

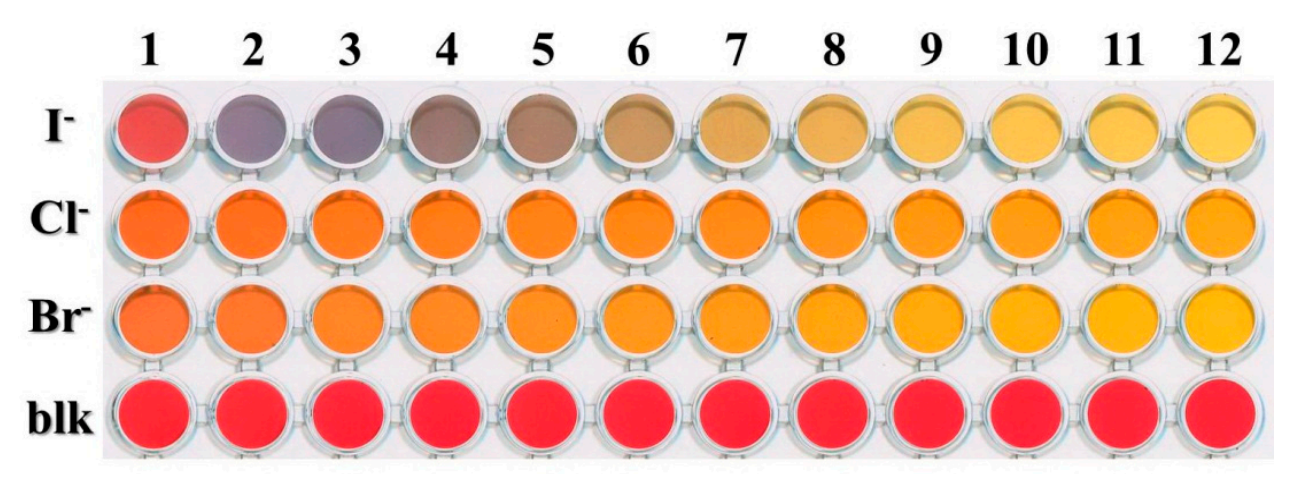

Figure 7. Example of calibration set employed for determination of chloride $(26.5 ; 30.1 ; 37.0 ; 40.4 ; 45.4 ; 50.4 ; 53.6 ; 61.4 ; 69.0$; $76.3 ; 83.3$ and $90.2 \mathrm{mM})$; bromide $(1.33 ; 1.50 ; 1.85 ; 2.02 ; 2.27 ; 2.52 ; 2.68 ; 3.07 ; 3.45 ; 3.81 ; 4.17$ and $4.51 \mathrm{mM})$ and iodide $(0.23$; $0.27 ; 0.30 ; 0.37 ; 0.40 ; 0.45 ; 0.50 ; 0.54 ; 0.61 ; 0.69 ; 0.76$ and $0.83 \mathrm{mM})$. The blk means blank which is given for comparison.

To eliminate any systematic error in the calibration as well as prediction steps, each measurement including the preparation of solution was performed in triplicate. The ANN architecture with one hidden layer was optimized and used for the prediction of values given in Table 4. Two strategies were tested. The first one involved the optimization procedure with all exp erimental data while the latter one treated each calibration matrix separately. Table 4 shows that both approaches yield almost the same results implying there is no systematic error in the experimental data. This was also proven using $t$-test where all values were lower than critical $t$-values (4.303 tabulated for $n=3, \alpha=95 \%$ [56]). In addition, the sensor shows the capability to distinguish halide mixtures both on qualitative and quantitative levels.

The successful application of sensor arrays using the microplate reader led us to mo- dify this approach for a digital scanner where the values are acquired in only three channels, Red, Green, and Blue. The results are given in Table 5. As can be seen, for all binary mixtures the reduction to 3 inputs for ANN architecture leads to similarly accurate results as with the plate readers which used 7 inputs. A digital scanner is a less expensive alternative compared to a microplate reader, and therefore can be used for routine analyses. 
Table 4. The results of analysis of halide mixture by ANN analysis of the experimental data obtained from the plate reader (see details in Figure 7).

\begin{tabular}{lcccccc}
\hline \multirow{2}{*}{$\begin{array}{l}\text { Halides } \\
\text { Mixture }\end{array}$} & $\mathbf{X}^{-}$ & \multicolumn{3}{c}{$c_{\mathrm{Br}, c_{\mathrm{Cl}} / \mathbf{m M}, c_{\mathrm{I}} / \mathbf{M M}}$} & \multicolumn{2}{c}{$t$-Value } \\
\cline { 3 - 6 } & & Given & \multicolumn{2}{c}{ Found $\pm \mathbf{s}$} & \\
\cline { 3 - 6 } & & & Separate & Simultaneous & Separate & Simultaneous \\
\hline \multirow{2}{*}{$\mathrm{Cl}^{-}: \mathrm{Br}^{-}$} & $\mathrm{Cl}$ & 19.20 & $15.6 \pm 1.7$ & $21.1 \pm 1.1$ & 3.65 & 3.08 \\
& $\mathrm{Br}$ & 1.15 & $1.05 \pm 0.16$ & $1.14 \pm 0.13$ & 1.09 & 0.16 \\
\hline & $\mathrm{Cl}$ & 9.80 & $9.42 \pm 0.61$ & $10.32 \pm 0.49$ & 1.00 & 1.94 \\
$\mathrm{Cl}^{-}: \mathrm{I}^{-}$ & $\mathrm{I}$ & 90.9 & $90.3 \pm 17.4$ & $96.4 \pm 6.7$ & 0.09 & 1.34 \\
& $\mathrm{Cl}$ & 28.30 & $27.0 \pm 5.8$ & $31.8 \pm 4.3$ & 0.36 & 1.48 \\
& $\mathrm{I}$ & 74.1 & $78.4 \pm 5.5$ & $74.3 \pm 5.8$ & 1.34 & 0.05 \\
$\mathrm{Br}^{-}: \mathrm{I}^{-}$ & $\mathrm{Br}$ & 0.78 & $1.06 \pm 0.52$ & $1.04 \pm 0.65$ & 0.94 & 0.71 \\
& $\mathrm{I}$ & 38.5 & $50.6 \pm 21.9$ & 38.5 & \\
\hline
\end{tabular}

${ }^{a}$ standard deviation, s, could not be calculated due to the same results obtained by ANN.

\subsection{Test Strips for Halides Determination}

Based on the results described in the previous section we have prepared a test paper strip by dipping the filtration paper with immobilized Tl(III)-PAR sensor in the solution of halide mixtures. The behavior of the Tl(III)-PAR strip is very similar to the solution of the sensor in the microplate (compare Figures 7 and 8). As can be seen in Figure 9, the limit of detection is also satisfactory for both the iodide and chloride solutions.

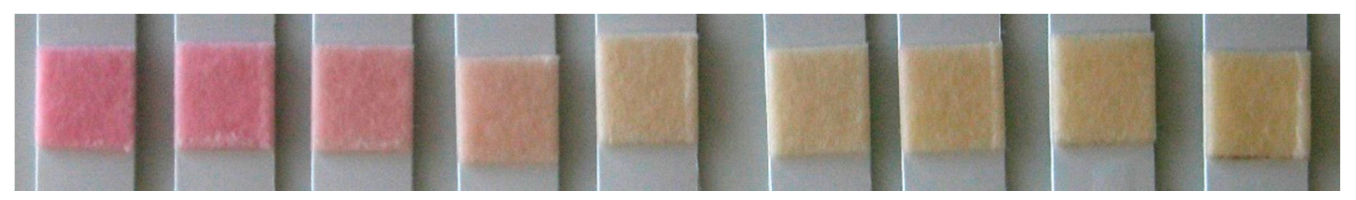

Figure 8. Example of calibration set for iodide determination (from left to right—blank, 0.05, 0.125, 0.25, 0.5, 1.25, 2.5, 5, $25 \mathrm{mM})$. Tl(III)-PAR complex $\left(c_{\mathrm{Tl}} \sim 0.5 \mathrm{mM}\right.$, ratio $\left.1: 1\right)$.

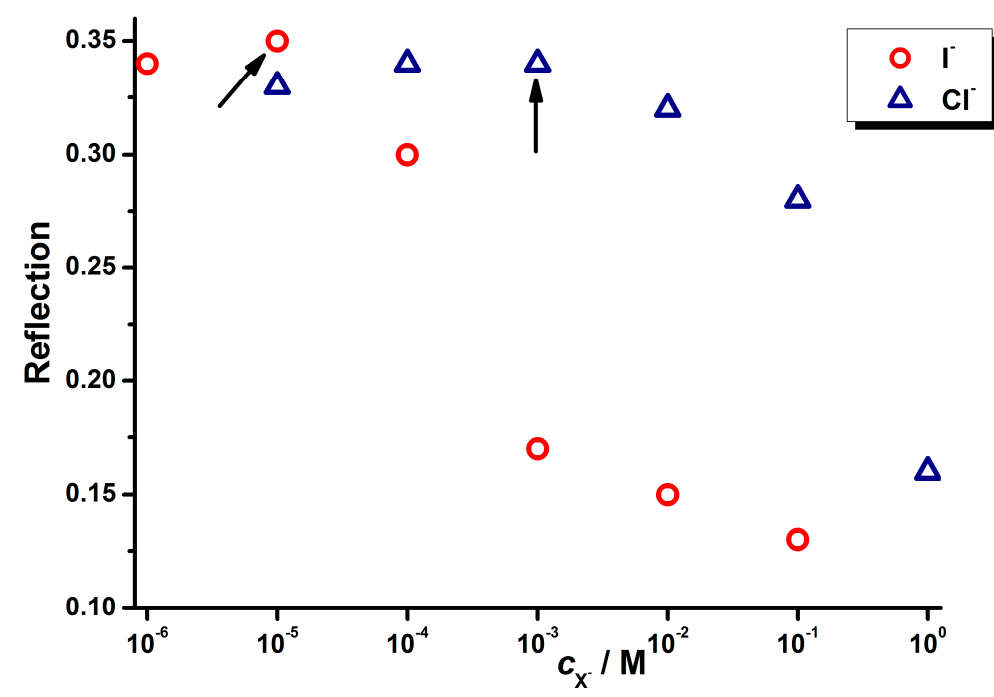

Figure 9. The reflection for green channel as a function of iodide and chloride concentration. The limit of detection was estimated as $10^{-5}-10^{-4} \mathrm{M}$ for iodide and $10^{-3}-10^{-2} \mathrm{M}$ for chloride using Tl:PAR 1:1 complex $\left(C_{\mathrm{Tl}}=0.5 \mathrm{mM}\right)$. 
Table 5. The results of analysis of halide mixture by ANN analysis of experimental data obtained from a digital scanner (see details in Figure 9).

\begin{tabular}{|c|c|c|c|c|c|c|}
\hline \multirow{3}{*}{$\begin{array}{l}\text { Halides } \\
\text { Mixture }\end{array}$} & \multirow{3}{*}{$X^{-}$} & \multicolumn{3}{|c|}{$c_{\mathrm{I}}, c_{\mathrm{Br}}, c_{\mathrm{Cl}} / \mathrm{mM}$} & \multirow{2}{*}{\multicolumn{2}{|c|}{$t$-Value }} \\
\hline & & \multirow{2}{*}{ Given } & \multicolumn{2}{|c|}{ Found $\pm s$} & & \\
\hline & & & Separate & Simultaneous & Separate & Simultaneous \\
\hline \multirow{2}{*}{$\mathrm{Cl}^{-}: \mathrm{Br}^{-}$} & $\mathrm{Cl}$ & 30.20 & $26.5 \pm 4.0$ & $28.4 \pm 1.8$ & 1.59 & 1.64 \\
\hline & $\mathrm{Br}$ & 1.51 & $1.38 \pm 0.14$ & $1.51^{\mathrm{a}}$ & 1.65 & - \\
\hline \multirow{4}{*}{$\mathrm{Cl}^{-}: \mathrm{I}^{-}$} & $\mathrm{Cl}$ & 22.91 & $24.8 \pm 4.1$ & 21.88 & 0.78 & - \\
\hline & I & 0.15 & $0.17 \pm 0.01$ & $0.17 \pm 0.02$ & 3.46 & 1.73 \\
\hline & $\mathrm{Cl}$ & 19.05 & $24.0 \pm 4.2$ & $21.88^{a}$ & 2.07 & - \\
\hline & I & 0.23 & $0.26 \pm 0.01$ & $0.27 \pm 0.02$ & 5.20 & 3.46 \\
\hline \multirow{2}{*}{$\mathrm{Br}^{-}: \mathrm{I}^{-}$} & $\mathrm{Br}$ & 1.32 & $1.25 \pm 0.25$ & $1.10^{\mathrm{a}}$ & 0.50 & - \\
\hline & I & 0.15 & $0.16 \pm 0.01$ & $0.16 \pm 0.02$ & 1.73 & 0.86 \\
\hline
\end{tabular}

${ }^{\mathrm{a}}$ standard deviation, s, could not be calculated due to the same results obtained by ANN.

To carry out quantitative analysis analogously to microplate reader and digital scanner, the change of reflection parameter was measured by commercial densitometer for different iodide concentrations in both blue and green channels (Figure 9). Firstly, the degradation of the ternary $\mathrm{Tl}(\mathrm{III})$-PAR-iodide complex may take place while the released azodye is characterized by the absorption band at $400 \mathrm{~nm}$ (Figure 2). This process is accompanied by the saturation of the green channel as well as an increase of the signal corresponding to the blue channel. This feature can be used for widening of the dynamic range. Such a behavior was not observed for bromide and chloride.

\section{Conclusions}

The present study describes the development of an optical chemosensor based on a thalium(III) metal complex with the PAR azodye. The method described here is suitable for spectroscopic qualitative as well as quantitative determination of halide ions $\left(\mathrm{Cl}^{-}, \mathrm{Br}^{-}, \mathrm{I}^{-}\right)$. The sufficiently large color change $(\Delta \lambda \approx 120 \mathrm{~nm})$ in aqueous solution as a consequence of the ligand substitution reaction in $\mathrm{Tl}(\mathrm{PAR})$ complexes can be used in an inexpensive "naked-eye" chemosensor frequently used in so-called dipstick mode with densitometer. The single Tl(PAR) chemosensor in conjunction with the data treatment by ANN was successfully used for multicomponent analysis of halides making it a first example of its kind in the literature. The method was simplified and adopted for routine analysis of halide mixtures using a microplate reader which can be replaced by a less expensive digital scanner. The sensor array analysis is particularly useful for speciation analysis or construction of more complex sensor arrays consisting of other halide chemosensors, when PAR can be replaced by other pyridyl-azodye, e.g., PANS with higher shift $\Delta \lambda=570-388=182 \mathrm{~nm}$ [53]. Finally, the $\mathrm{Tl}(\mathrm{PAR})$ colorimetric chemosensor could be applied to the test paper strip and used for rapid halide determination in real water samples.

Author Contributions: Conceptualization, P.L.; methodology, M.Š. and P.L.; investigation, M.Š. and P.L.; resources, P.L. and P.A.J.; writing-original draft preparation, M.Š. and P.L.; writing-review and editing, M.Š., P.L. and P.A.J.; visualization, M.Š. and P.L.; supervision, P.L.; project administration, P.L.; funding acquisition, P.L. and P.A.J. All authors have read and agreed to the published version of the manuscript.

Funding: This research was funded by Masaryk University (MUNI/A/1424/2019), Ministry of Education of the Czech Republic (LTC20044, CEITEC 2020-LQ 1601 program, ME09065) and EU (COST CA18202 NECTAR Action).

Data Availability Statement: Not applicable.

Acknowledgments: This work was supported by Masaryk University (MUNI/A/1424/2019), Ministry of Education of the Czech Republic (LTC20044, CEITEC 2020_LQ 1601 program, ME09065) 
and EU (COST CA18202 NECTAR Action). We also thank professor Zbyněk Prokop for technical assistance with measurement on microplate reader SUNRISE.

Conflicts of Interest: The authors declare no conflict of interest.

\section{Appendix A}

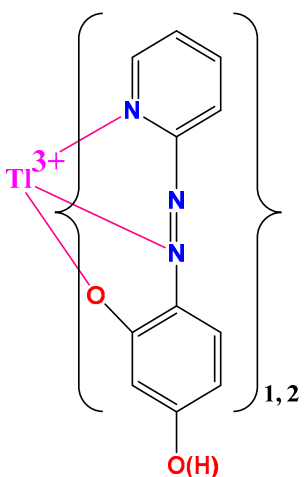

(a)

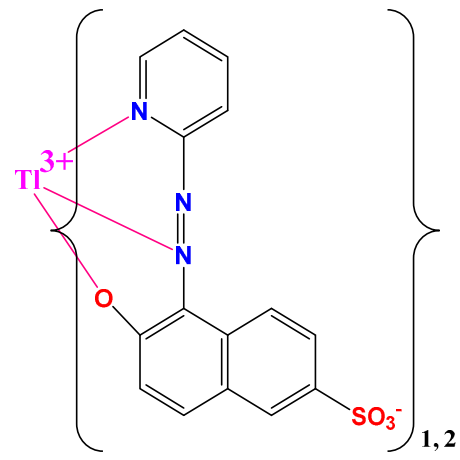

(b)

Figure A1. Description of system Tl(III)-PAR vs. Tl(III)-PANS: (a) Tl(III)-PAR 4-(2pyridylazo)resorcinol (PAR); (b) Tl(III)-PANS 2-(2-pyridylazo)-1-naphthol-4-sulfonic acid (PANS).

The Tl(III) ion interacts with PAR reagent $\left(\mathrm{p} K_{\mathrm{a} 1}=2.8-3.1\right.$, ligand species are $\mathrm{LH}_{3}{ }^{+}$ and $\mathrm{LH}_{2}$ ) which forms Tl(III) metal complexes of the Tl:L 1:1 [43,47-49,57] and 1:2 [47,48] ratios. In acidic medium ( $\mathrm{pH}$ 1.0-3.5) and in the excess of the ligand over $\mathrm{Tl}(\mathrm{III})$, there is evidence of formation of two complexes [47,48]. In excess of Tl(III) ion $\left(c_{\mathrm{L}}=0.02 \mathrm{mM}\right.$, $\left.c_{\mathrm{Tl}}=1.2 \mathrm{mM},-\log \left[\mathrm{H}^{+}\right]=0.1-0.8\right)$, the protonated $\mathrm{TlLH}^{2+}$ species $\left(\lambda_{\max }=524 \mathrm{~nm}\right.$, $\varepsilon=1.91 \times 10^{4} \mathrm{M}^{-1} . \mathrm{cm}^{-1}$ ) is formed first:

$$
\mathrm{Tl}^{3+}+\mathrm{LH}_{3}{ }^{+} \Leftrightarrow \mathrm{TlLH}^{2+}+2 \mathrm{H}^{+}
$$

Then, at $-\log \left[\mathrm{H}^{+}\right]>1.3$ (in $\mathrm{Tl}(\mathrm{III})$ excess), this species undergoes deprotonation of p-phenolic group [47,48]:

$$
\mathrm{TlLH}^{2+} \Leftrightarrow \mathrm{TlL}^{+}+\mathrm{H}^{+}
$$

and the new species $\left(\lambda_{\max }=530 \mathrm{~nm}, \varepsilon=2.7 \times 10^{4} \mathrm{M}^{-1} . \mathrm{cm}^{-1}\right)$ is formed. In addition, the $\mathrm{Tl}(\mathrm{III})$ reacts with $\mathrm{LH}_{3}{ }^{+}$ligand species and most likely forms $\mathrm{TlLH}^{2+}$ complex $\left(-\log \left[\mathrm{H}^{+}\right]=0.1-1.0, I=2.0 \mathrm{M}(\mathrm{Na}, \mathrm{H}) \mathrm{ClO}_{4}, \mathrm{Tl}(\mathrm{III})\right.$ excess over ligand) in ms scale [58] while the intramolecular hydrogen bonding including o-phenolic group is responsible for slow formation of the $\mathrm{Tl}(\mathrm{III})$ complex [58]. The rate-determining step of overall formation reaction is a release of water molecule from $\mathrm{Tl}(\mathrm{III})$ aqua ion [58].

On the other hand, at $-\log \left[\mathrm{H}^{+}\right]<2.5$ in ligand excess, two species are simultaneously formed [47,48]:

$$
\begin{gathered}
\mathrm{Tl}^{3+}+\mathrm{LH}_{3}{ }^{+} \Leftrightarrow \mathrm{TlLH}^{2+}+2 \mathrm{H}^{+} \\
\mathrm{TlLH}^{2+}+\mathrm{LH}_{3}{ }^{+} \Leftrightarrow \mathrm{Tl}(\mathrm{LH})_{2}{ }^{+}+2 \mathrm{H}^{+}
\end{gathered}
$$

The latter Tl(III) complex is quantitatively formed at $-\log \left[\mathrm{H}^{+}\right]=3.3-3.5$ with limiting value $\varepsilon=3.0 \times 10^{4} \mathrm{M}^{-1} . \mathrm{cm}^{-1}\left(\lambda_{\max }=530 \mathrm{~nm}\right)[47,48]$. This explains why other authors working at lower $\mathrm{pH}(\mathrm{pH} \sim 2.2$ [43], $\mathrm{pH} 3-4$, in an unbuffered solution [49] where the competition with $\mathrm{OH}^{-}$ligand may take place [49]) have not detected the 1:2 complex. Due to sequence ambiguity of the protonation process of hydroxyl group in o- and p-position of the phenolic moiety of the ligand, there is unclear definition of stability constant for $\mathrm{Tl}(\mathrm{III})$ complex species and consequently, different values are found in the literature [39,43,47-49]. 
To overcome this problem by simplification of analytical reagent while retaining the main structural motif, the PANS (2-(2-pyridylazo)-1-naphthol-4-sulfonic acid) as analytical reagent was utilized. Here, in the ligand excess $\left(c_{\mathrm{Tl}}=0.02 \mathrm{mM},-\log \left[\mathrm{H}^{+}\right]=0-2\right)$, only two species are formed [52]:

$$
\begin{aligned}
\mathrm{Tl}^{3+}+\mathrm{H}_{2} \mathrm{~L}^{+} & \Leftrightarrow \mathrm{TlL}^{2+}+2 \mathrm{H}^{+} \\
\mathrm{TlL}^{2+}+\mathrm{H}_{2} \mathrm{~L}^{+} & \Leftrightarrow \mathrm{TlL}_{2}^{+}+2 \mathrm{H}^{+}
\end{aligned}
$$

Based on the spectral data, the chemical model consisting of two species $\left(\mathrm{TlL}^{2+}\right.$ : $\log \beta_{1}=14.18 \pm 0.05, \varepsilon=1.9460 \times 10^{4} \mathrm{M}^{-1} . \mathrm{cm}^{-1}, \mathrm{TlL}_{2}{ }^{+}: \log \beta_{2}=26.52 \pm 0.10, \varepsilon=3.35 \times 10^{4} \mathrm{M}^{-1} \cdot \mathrm{cm}^{-1}$ both at $\lambda_{\max }=540 \mathrm{~nm}$ [53]) was proposed. The distribution diagram shows that the PANS ligand is more efficient for sequestering of Tl(III) ion than hydroxide $\left(\log \beta_{1}=12.8\right.$, $\log \beta_{2}=25.3$ [59], see Figure A2) where 1:1 complex is formed at $-\log \left[\mathrm{H}^{+}\right] \sim 1-2$ and 1:2 complex at $-\log \left[\mathrm{H}^{+}\right]>3$.
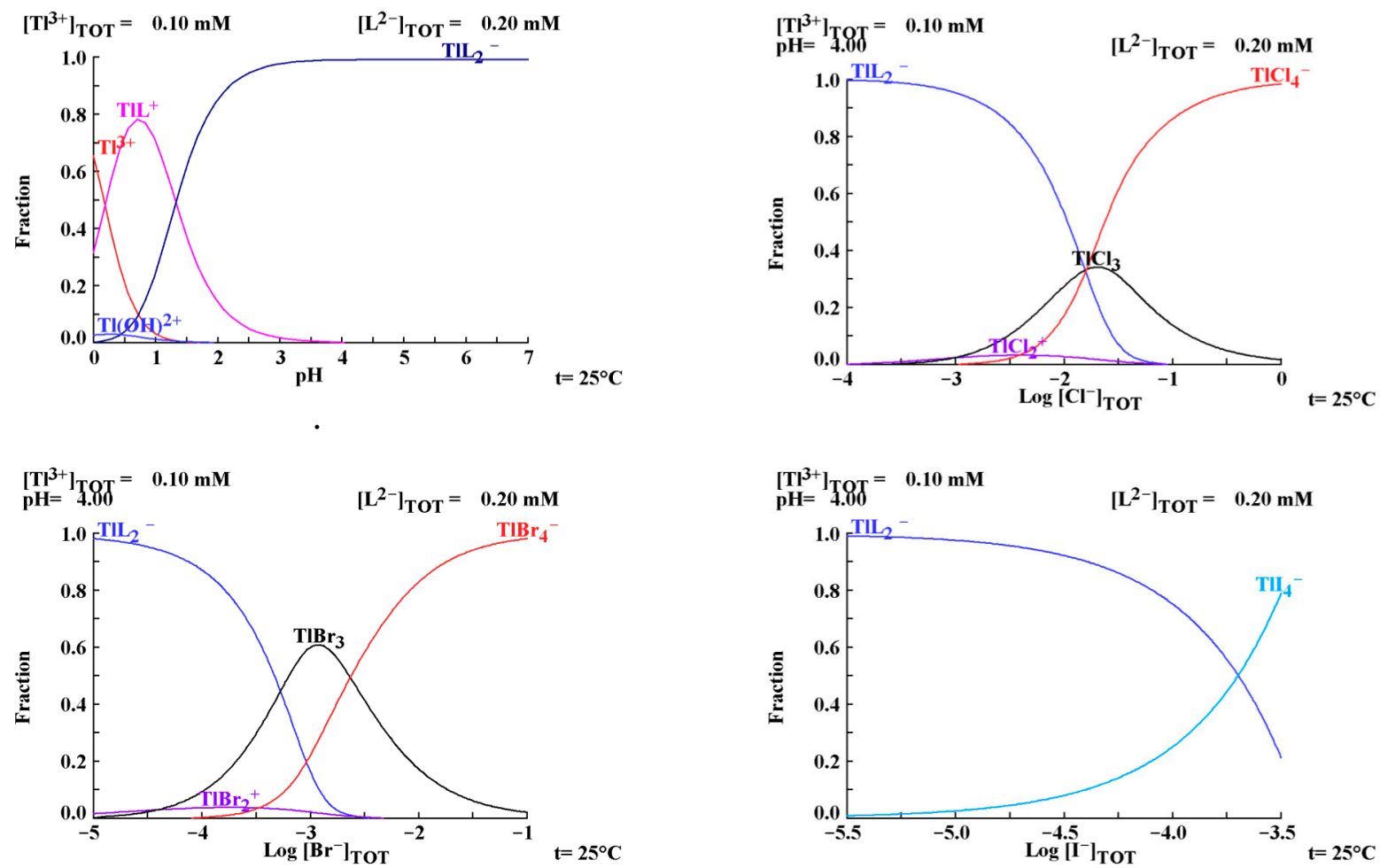

Figure A2. The distribution diagram of Tl(III)-PANS system at $\mathrm{pH}=4.0$ in the presence of chloride, bromide and iodide.

The Tl(III) complexes of both ligands consisting of pyridyl-azo motif are more stable from kinetic point of view than the complexes of ligands with other heterocyclic structural binding site (e.g., 4-(thiazolylazo)resorcinol = TAR) [48]. Therefore pyridylazo-ligands have been chosen for $\mathrm{Tl}(\mathrm{III})$ complex chemosensor. In addition, the Tl(III) complexes with pyridylazo-ligands are capable of formation of ternary species with some bulky anions (e.g., perchlorate, nitrate) [53,57] and positively charged bases (e.g,. antipyrine, [57]) in organic solvents.

For 1:1 complex, the Tl(III) ion forms with halides, i.e., chloride, bromide, iodide more stable $\mathrm{TlX}_{4}{ }^{-}$complexes than with azodyes (Table A1). The ligand release from $\mathrm{Tl}(\mathrm{III})$ complexes is proportional to the excess of the halide and to the stability of $\mathrm{TlX}_{4}{ }^{-}$species $\left(\mathrm{Cl}^{-}\right.$: $\left.18.3, \mathrm{Br}^{-}: 23.9, \mathrm{I}^{-}: 35.7[44,50-52,59]\right)$. This effect was already described for spectrophotometric $[43,47]$ and extraction-spectrophotometric [57] determination of thallium(III).

Assuming the following chemical exchange reactions:

$$
\mathrm{TlL}+4 \mathrm{X}^{-} \Leftrightarrow \mathrm{TlX}_{4}^{-}+\mathrm{L} K_{\mathrm{TlL}, \mathrm{X}}
$$




$$
\mathrm{TlL}_{2}+4 \mathrm{X}^{-} \Leftrightarrow \mathrm{TlX}_{4}^{-}+2 \mathrm{~L} \quad K_{\mathrm{TlL} 2, \mathrm{X}}
$$

then their equilibrium constants can be calculated as

$$
\begin{gathered}
\log K_{\mathrm{TIL}, \mathrm{X}}=\log \beta\left(\mathrm{TlX}_{4}{ }^{-}\right)-\log \beta(\mathrm{TIL}) \\
\log K_{\mathrm{TlL} 2, \mathrm{X}}=\log \beta\left(\mathrm{TlX}_{4}^{-}\right)-\log \beta\left(\mathrm{TlL}_{2}\right)
\end{gathered}
$$

At $\mathrm{pH}=$ const., the previous relationships are valid for conditional equilibrium constants.

Table A1. The equilibrium constants of exchange reactions of the system Tl(III)-PANS-halide $\left(\log \beta(\mathrm{TlL})=14.18, \log \beta\left(\mathrm{TlL}_{2}\right)=26.52[53,59]\right)$.

\begin{tabular}{cccc}
\hline Halide & $\log \beta\left(\mathrm{TlX}_{\mathbf{4}^{-}}\right)$ & $\log K_{\mathrm{TlL}, \mathrm{X}}$ & $\log K_{\mathrm{TlL} 2, \mathrm{X}}$ \\
\hline $\mathrm{Cl}^{-}$ & 18.3 & 4.1 & -8.2 \\
\hline $\mathrm{Br}^{-}$ & 23.9 & 9.7 & -2.6 \\
\hline $\mathrm{I}^{-}$ & 35.7 & 21.5 & 9.2 \\
\hline
\end{tabular}

Similarly, the Equations (A9) and (A10) can be also used for calculation of (conditional) equilibrium constants of Tl(III)-PAR complexes

$$
\begin{aligned}
\log \beta(\mathrm{TlL}) & =\log \beta\left(\mathrm{TlX}_{4}^{-}\right)-\log K_{\mathrm{TIL}, \mathrm{X}} \\
\log \beta\left(\mathrm{TlL}_{2}\right) & =\log \beta\left(\mathrm{TlX}_{4}{ }^{-}\right)-\log K_{\mathrm{TlL}, \mathrm{X} 2}
\end{aligned}
$$

Therefore, the Equation (A12) can be used to estimate the conditional stability constants of $\mathrm{TlL}_{2}$ complex from experimental data at $\mathrm{pH} \sim 4.0$ (see Figure 3). The estimated value of conditional constant $\left(\log \beta^{\prime}\left(\mathrm{TlL}_{2}\right)=22.6\right.$ - see Table A2) can be recalculated to thermodynamic value $\log \beta\left(\mathrm{TlL}_{2}\right)=25.8$ (Tl(III)-PAR) using protonation constants of PAR (3.1, 5.6 [47]) which is comparable with value $\log \beta\left(\mathrm{TlL}_{2}\right)=26.6$ (Tl(III)-PANS). Likewise, the conditional constant $\log \beta^{\prime}(\mathrm{TlL})=16.3(\mathrm{pH} \sim 4.0)$ was calculated from the values for $\log$ $\beta(\mathrm{TlL})=17.9$ [47].

Table A2. The equilibrium constants of exchange reactions of the system Tl(III)-PAR-halide ( $\mathrm{pH}=4.0)$.

\begin{tabular}{cccc}
\hline Halide & $\log \beta\left(\mathrm{TlX}_{\mathbf{4}^{-}}\right)$ & $\log K_{\mathrm{TlL2}, \mathrm{X}}$ & $\log \beta^{\prime}\left(\mathrm{TlL}_{\mathbf{2}}\right)$ \\
\hline $\mathrm{Cl}^{-}$ & 18.3 & -4.6 & 22.9 \\
\hline $\mathrm{Br}^{-}$ & 23.9 & 1.6 & 22.3 \\
\hline Average value & & & 22.6 \\
\hline
\end{tabular}

\section{References}

1. Nollet, L.M.L. Handbook of Water Analysis; CRC Press Boca Raton: Boca Raton, Fl, USA, 2007.

2. Qu, F.; Li, N.B.; Luo, H.Q. Polyethyleneimine-Templated Ag Nanoclusters: A New Fluorescent and Colorimetric Platform for Sensitive and Selective Sensing Halide Ions and High Disturbance-Tolerant Recognitions of Iodide and Bromide in Coexistence with Chloride under Condition of High Ionic Strength. Anal. Chem. 2012, 84, 10373-10379. [CrossRef] [PubMed]

3. Shen, Z; Li, H.; Feng, L. Using ratiometric indicator-displacement assays in semi-quantitative colorimetric determination of chloride, bromide, and iodide anions. Analyst 2011, 136, 5025-5029. [CrossRef] [PubMed]

4. Jeffery, G.H.; Bassett, J.; Mendham, J.; Denney, R.C. Vogel's Textbook of Quantitative Chemical Analysis; Longman: Essex, UK, 1989.

5. Janata, J. Principles of Chemical Sensors; Springer: Heidelberg, Germany, 2010.

6. Banica, F.-G. Chemical Sensors and Biosensors; Wiley: Chichester, UK, 2012.

7. Boček, P.; Deml, M.; Gebauer, P.; Dolník, V. Analytical Isotachophoresis; VCH Weinheim (FRG): Weinheim, Germany, 1988.

8. Foret, F.; Křivánková, L.; Boček, P. Capillary Zone Electrophoresis; VCH Weinheim (FRG): Weinheim, Germany, 1993.

9. Buszewski, B.; Dziubakiewicz, E.; Szumski, M. (Eds.) Electromigration Techniques-Theory and Practice; Springer: Berlin, Germany, 2013.

10. Wang, B.; Anslyn, E.V. (Eds.) Chemosensors. Principles, Strategies and Applications; Wiley: Hoboken, NJ, USA, 2011. 
11. Snowden, T.S.; Anslyn, E.V. Anion recognition: Synthetic receptors for anions and their application in sensors. Current Op. Chem. Biol. 1999, 3, 740-746. [CrossRef]

12. Nguyen, B.T.; Anslyn, E.V. Indicator-displacement assays. Coord. Chem. Rev. 2006, 250, 3118-3127. [CrossRef]

13. Anslyn, E.V. Supramolecular analytical chemistry. J. Org. Chem. 2007, 72, 687-699. [CrossRef]

14. You, L.; Zha, D.; Anslyn, E.V. Recent Advances in Supramolecular Analytical Chemistry Using Optical Sensing. Chem. Rev. 2015, 115, 7840-7892. [CrossRef]

15. Anzenbacher, P., Jr.; Lubal, P.; Buček, P.; Palacios, M.A.; Kozelkova, M.E. A practical approach to optical cross-reactive sensor arrays. Chem. Soc. Rev. 2010, 39, 3954-3979. [CrossRef]

16. Palacios, M.A.; Nishiyabu, R.; Marquez, M.; Anzenbacher, P., Jr. Supramolecular Chemistry Approach to the Design of a High-Resolution Sensor Array for Multi-anion Detection in Water. J. Am. Chem. Soc. 2007, 129, 7538-7544. [CrossRef] [PubMed]

17. Palacios, M.A.; Wang, Z.; Montes, V.A.; Zyryanov, G.V.; Anzenbacher, P., Jr. Rational Design of a Minimal Size Sensor Array for Metal Ion Detection. J. Am. Chem. Soc. 2008, 130, 10307-10314. [CrossRef]

18. Liu, Y.; Palacios, M.A.; Anzenbacher, P., Jr. The power of the weak: Recognition of ion pairs in water using a simple array sensor. Chem. Comm. 2010, 46, 1860-1862. [CrossRef]

19. Feng, L.; Li, H.; Li, X.; Chen, L.; Shen, Z.; Guan, Y. Colorimetric sensing of anions in water using ratiometric indicator-displacement assay. Anal. Chim. Acta 2012, 743, 1-8. [CrossRef]

20. Qian, S.; Lin, H. A facile approach to cross-reactive colorimetric sensor arrays: An application in the recognition of the 20 natural amino acids. RSC Adv. 2014, 4, 29581. [CrossRef]

21. Li, H.; Jia, M.; Askim, J.R.; Zhang, Y.; Duan, C.; Guana, Y.; Feng, L. An array sensor consisting of a single indicator with multiple concentrations and its application in ion discrimination. Chem. Commun. 2014, 50, 15389-15392. [CrossRef]

22. Wang, Y.; Huo, D.; Wu, H.; Li, J.; Zhang, Q.; Deng, B.; Zhou, J.; Yang, M.; Hou, C. A visual sensor array based on an indicator displacement assay for the detection of carboxylic acids. Microchim. Acta 2019, 186, 496. [CrossRef] [PubMed]

23. Smith, D.G.; Topolnicki, I.L.; Zwicker, V.E.; Jolliffe, K.A.; New, E.J. Fluorescent sensing arrays for cations and anions. Analyst 2017, 142, 3549-3563. [CrossRef]

24. Fan, J.; Ding, L. Single-system based discriminative optical sensors: Different strategies and versatile applications. Analyst 2018, 143, 3775-3788. [CrossRef]

25. Kangas, M.J.; Burks, R.M.; Atwater, J.; Lukowicz, R.M.; Williams, P.; Holmes, A.E. Colorimetric Sensor Arrays for the Detection and Identification of Chemical Weapons and Explosives. Crit. Rev. Anal. Chem. 2017, 47, 138-153. [CrossRef] [PubMed]

26. Yawer, M.A.; Havel, V.; Šindelář, V. A Bambusuril Macrocycle that Binds Anions in Water with High Affinity and Selectivity. Angew. Chem. Int. Ed. 2015, 54, 276-279. [CrossRef]

27. Lisbjerg, M.; Nielsen, B.E.; Milhoj, B.O.; Sauer, S.P.A.; Pittelkow, M. Anion binding by biotin [6]uril in water. Org. Biomol. Chem. 2015, 13, 369-373. [CrossRef] [PubMed]

28. Sommer, F.; Marcus, Y.; Kubik, S. Effects of Solvent Properties on the Anion Binding of Neutral Water-Soluble Bis(cyclopeptides) in Water and Aqueous Solvent Mixtures. ACS Omega 2017, 2, 3669-3680. [CrossRef] [PubMed]

29. Kaur, N.; Kaur, G.; Fegade, U.A.; Singh, A.; Sahoo, S.K.; Kuwar, A.S.; Singh, A. Anion sensing with chemosensors having multiple -NH recognition Units. Trends Anal. Chem. 2017, 95, 86-109. [CrossRef]

30. Amendola, V.; Bergamaschi, G.; Boiocchi, M.; Fabbrizzi, L.; Poggi, A.; Zema, M. Halide ion inclusion into a dicopper(II) bistren cryptate containing 'active' 2,5-dimethylfuran spacers: The origin of the bright yellow colour. Inorg. Chim. Acta 2008, 361, 4038-4046. [CrossRef]

31. Alibrandi, G.; Amendola, V.; Bergamaschi, G.; Dollenz, R.; Fabbrizzi, L.; Licchelli, M.; Lo Vecchio, C. An Automatic Molecular Dispenser of Chloride. Chem. Eur. J. 2013, 19, 3729-3734. [CrossRef]

32. Bergamaschi, G.; Boiocchi, M.; Perrone, M.L.; Poggi, A.; Viviania, I.; Amendola, V. Mixing the spacers in azacryptands: Effects on halide recognition. Dalton Trans. 2014, 43, 11352-11360. [CrossRef]

33. Invernici, M.; Ciarrocchi, C.; Dondi, D.; Fabbrizzi, L.; Lazzaroni, S.; Licchelli, M.; Boiocchi, M.; Bonizzoni, M. Bimacrocyclic Effect in Anion Recognition by a Copper(II) Bicyclam Complex. ACS OMEGA 2018, 3, 15692-15701. [CrossRef]

34. Boiocchi, M.; Bonizzoni, M.; Ciarrocchi, C.; Fabbrizzi, L.; Invernici, M.; Licchelli, M. Anion Recognition in Water, Including Sulfate, by a Bicyclam Bimetallic Receptor: A Process Governed by the Enthalpy/Entropy Compensatory Relationship. Chem. Eur. J. 2018, 24, 5659-5666. [CrossRef]

35. Marshall, S.R.; Singh, A.; Wagner, J.N.; Busschaert, N. Enhancing the selectivity of optical sensors using synthetic transmembrane ion transporters. Chem. Comm. 2020, 56, 14455-14458. [CrossRef]

36. Holzbecher, Z.; Diviš, L.; Král, M.; Šůcha, L.; Vláčil, F. Handbook of Organic Reagents in Inorganic Analysis; Ellis Horwood: Chichester, UK, 1976.

37. Ueno, K.; Imamura, T.; Cheng, K.I. Handbook of Organic Analytical Reagents; CRC Press Boca: Raton, FL, USA, 1992.

38. Langová-Hniličková, M.; Sommer, L. The Coordination and Analytical Chemsitry of n-Heterocyclic azo Dyes. Folia Fac. Sci. Natur. Univ. Purkynianae Brunensis 1968, 9, 1-131.

39. Anderson, R.G.; Nickless, G. Heterocyclic Azo Dyestuffs in Analytical Chemistry. A Review. Analyst 1967, 92, 207-238. [CrossRef] [PubMed]

40. Lubal, P.; Farková, M. Application of artificial neural networks in speciation analysis. In Utilizing of Bio-Electrochemical and Mathematical Methods in Biological Research; Kizek, R., Adam, V., Eds.; Research Signpost: Kerala, India, 2007. 
41. Busev, A.I.; Tiptsova, V.G. Research in thallium(III) analytical chemistry. 5. On complexometric indicators for Tl(III) ion analysis. Zh. Anal. Khim. 1960, 15, 573-580.

42. Musso, S. Untersuchung von Gleichgewichten in wässriger Lösung und Kristallstrukturbestimmung von Komplex des Thallium(III) mit Chelatliganden. Ph.D. Thesis, ETH Zürich, Rämistrasse, Switzerland, 1993.

43. Gramlich, V.; Lubal, P.; Musso, S.; Anderegg, G. The stability of metal N,N,N ',N '-tetrakis(2-aminoethyl)ethane-1,2-diamine (= penten) complexes and the X-ray crystal structure of $\left[\mathrm{Tl}\left(\mathrm{NO}_{3}\right)(\right.$ penten$\left.)\right]\left(\mathrm{NO}_{3}\right)_{2}$. Helv. Chim. Acta 2001, 84, 623-631. [CrossRef]

44. Chen, B.; Lubal, P.; Musso, S.; Anderegg, G. Equilibria with the thallium(III)triethylenetetraminehexaacetate anion [Tl(ttha) $]^{3-}$ in aqueous solution. Anal. Chim. Acta 2000, 406, 317-323. [CrossRef]

45. John Peter, A.L.; Viraraghavan, T. Thallium: A review of public health and environmental concerns. Environ. Int. 2005, 31, 493-501. [CrossRef]

46. Belzile, N.; Chen, Y.-W. Thallium in the environment: A critical review focused on natural waters, soils, sediments and airborne particles. Appl. Geochem. 2017, 84, 218-243. [CrossRef]

47. Hniličková, M.; Sommer, L. Spectrophotometric determination of thallium with 4-(2-pyridylazo)resorcinol and 4-(2thiazolylazo)resorcinol. Talanta 1968, 16, 83-94. [CrossRef]

48. Sommer, L.; Voznica, P. On the reaction of thallium(III) with heterocyclic azo dyes. Scripta Fac. Sci. Natur. Univ. Purkynianae Brunensis 1980, 10, 81-92.

49. Biryuk, E.A.; Ravitska, R.V. Interaction of Thallium(III) Ions with Pyridylazonaphthol and Pyridylazoresorcinol. Zh. Anal. Khim. 1971, 26, 1767-1769.

50. Glaser, J.; Henriksson, U. Thallium-205 Nuclear Magnetic Resonance Study of Thallium(III) Halide Complexes in Aqueous Solutions. J. Am. Chem. Soc. 1981, 103, 6642-6649. [CrossRef]

51. Johansson, L. The Complex Formation of Thallium(III) with Iodide in Aqueous Solution. Acta Chem. Scand. 1966, 20, 2156-2168. [CrossRef]

52. Blixt, J.; Györi, B.; Glaser, J. Determination of Stability Constants for Thallium(III) Cyanide Complexes in Aqeous Solution by means of ${ }^{13} \mathrm{C}$ and ${ }^{205} \mathrm{Tl}$ NMR. J. Am. Chem. Soc. 1989, 111, 7784-7791. [CrossRef]

53. Voznica, P.; Havel, J.; Sommer, L. The reactions of galium, indium and thallium with 2-(2-pyridylazo)-1-naphthol-4-sulfonic acid and their spectrophotometric determination. Collection Czechoslovak Chem. Commun. 1980, 45, 54-79. [CrossRef]

54. Sommer, L.; Kubáň, V.; Langová, M. Spectrophotometric Investigation of Complexes with Organic Reagents for the Optimization of Spectrophotometric Determinations (UV + VIS) of Inorganic Analytes. Fresenius Z. Anal. Chem. 1982, 310, 51-61. [CrossRef]

55. Havel, J.; Lubal, P.; Farková, M. Evaluation of chemical equilibria with the use of artificial neural networks. Polyhedron 2002, 21, 1375-1384. [CrossRef]

56. Harris, D.C. Quantitative Chemical Analysis; W.H. Freeman: New York, NY, USA, 1991.

57. Biryuk, E.A.; Ravitska, R.V. Mixed-Ligand Complexes of Aluminum and Thallium with 4-(2-Pyridylazo)-Resorcinol and Antipyrine. Zh. Anal. Khim. 1973, 28, 1500-1505.

58. Funada, R.; Imamura, T.; Fujimoto, M. Rate and Mechanism of the Complex Formation of Thallium(III) with 4-(2Pyridylazo)resorcinol (PAR) in Aqueous Solution. Bull. Chem. Soc. Japan 1979, 52, 1535-1536. [CrossRef]

59. Kotrlý, S.; Šůcha, L. Handbook of Chemical Equilibria in Analytical Chemistry; Ellis Horwood: Chichester, UK, 1985. 